www.nature.com/ejhg

\title{
LETTER
}

\section{Absence of association of fetal MTHFR C677T polymorphism with prenatal Down syndrome pregnancies}

European Journal of Human Genetics (2003) 11, 5. doi:10.1038/sj.ejhg.5200928

We were excited to peruse the short report 'C677T mutation in the 5,10-MTHFR gene and risk of Down syndrome in Italy' published in this year's June issue of the EJHG, by Stuppia L et al (2002), because it echoed our findings. We analysed 47 Caucasian pregnant patients with prenatal chromosomal defects, for MTHFR C677T polymorphism. We found 22 patients with foetal karyotype of Trisomy 21 , and among them three were 677TT, 10 were $677 \mathrm{CT}$, and nine were $677 \mathrm{CC}$ genotypes. However, we found 50 individuals with 677TT, 167 with $677 \mathrm{CT}$ and 158 with 677CC genotypes, among 375 control Caucasian infants. The mutant 677TT homozygosity in the Down syndrome pregnancies was $13.6 \%$ as compared to $13.3 \%$ in the Caucasian control infants, with an odds ratio of 1 . When we compared the mutant 677T allele frequency, the Down syndrome pregnancies displayed 0.364 as compared to 0.356 in the controls, with an odds ratio of 1 . Thus in our data we also did not find any correlation of MTHFR mutant 677TT homozygosity or mutant 677T allele frequency with the prenatal Down syndrome cases, as concluded by Stuppia et al (2002).

Krishna Yanamandra, Joseph A Bocchini Jr, Theodore $\mathrm{F}$ Thurmon Department of Pediatrics, LSU Health Sciences Center, 1501 Kings Hwy., Shreveport, Louisiana 71130, USA

\section{References}

1 Stuppia L, Gatta V, Gaspari AR et al: C677T mutation in the 5,10MTHFR gene and risk of Down syndrome in Italy. Eur J Hum Genet 2002; 10: 388-390.

2 Yanamandra K, Gadi I, Napper D, Chen H, Bocchini Jr JA, Thurmon TF, Dhanireddy R: MTHFR C677T polymorphism in pregnancies with Chromosomal Defects. Amer J Hum Genet 2001; 69: 431. 